\title{
A FRAMEWORK FOR GOOD GOVERNANCE IN PROJECT MANAGEMENT IN SOUTH AFRICA
}

\author{
K. Maharaj ${ }^{1}$, D. Heil ${ }^{2}$ and A.C.J. van Rensburg ${ }^{3}$ \\ ${ }^{1}$ Wits Business School \\ University of Witwatersrand, South Africa \\ ${ }^{2}$ Wits Business School \\ University of Witwatersrand, South Africa \\ heil.d@wbs.ac.za \\ ${ }^{3}$ Department of Industrial and Systems Engineering \\ University of Pretoria, South Africa \\ antoniej@up.ac.za
}

\begin{abstract}
In the context of predicted positive economic growth in South Africa for the next three years, the economic landscape could well be characterised by a growth in investment in South Africa. Some of the investment will be underpinned by infrastructure projects by state-owned enterprises. To access the funding required for these projects, South African entities may find themselves competing for investor funding. If South Africa and its corporations are to access international financing, it is important that the overall business environment - and the project environment in particular - is well governed. This article presents a framework that South African corporations can use to determine the governance structure and governance practices that apply to a project environment, within the context of broader corporate governance based on the second King Report on Corporate Governance for South Africa.
\end{abstract}

\section{OPSOMMING}

In die konteks van voorspelde positiewe groei in Suid-Afrika oor die volgende drie jare, behoort die ekonomiese landskap gekenmerk te word deur beleggingsgroei in Suid-Afrika. Sommige van hierdie beleggings sal ondersteun word deur infrastruktuurontwikkeling deur staatsbeheerde organisasies. Vir die voorsiening van investeringskapitaal tot hierdie projekte sal Suid-Afrikaanse entiteite in kompetisie staan vir internastionale beleggersfondse. Hierdie artikel stel 'n raamwerk voor waarbinne Suid-Afrikaanse organisasies beheerstrukture en beheerpraktyke kan toepas in 'n projekbestuursomgewing soos voorgestel deur die tweede King verslag oor korporatiewe bestuur vir Suid Afrika.

\footnotetext{
${ }^{1}$ The author was enrolled for the Masters in Business Administration at the Wits Business School, University of Witwatersrand.
} 


\section{INTRODUCTION}

The South African economy has grown at an average 3.2\% per year over the past four years. There is an expectation that it will expand by between $4 \%$ and $4.5 \%$ over the next three years [10]. This is as a result of sound macro-economic performance and monetary management, improved competitiveness, structural reform, and a fiscal policy framework designed to underpin sustainable growth and investment [10]. One of the critical development policies for the next decade will be to build a more efficient economic landscape, as the pace of investment in modern transport, communication, water, and energy networks is increased [10].

In February 2005, in his address to the second joint sitting of South Africa's third democratic Parliament in Cape Town, President Thabo Mbeki outlined the broad objectives of the programme of action: to increase investment in the economy, lower the cost of doing business in South Africa, improve economic inclusion, and provide the skills required by the economy [11]. Since May 2004, investment plans for transport logistics, electricity, and water resources in excess of R180 billion have been developed [11].

Against the backdrop of the projected economic growth and development, an analysis of the investment plans indicates that most of these will be executed on a project basis. Given the likely value of the proposed investments, it can be concluded that the requirement for funding both locally and internationally will be significant.

If South African corporations are to compete for finance for the projects they may be undertaking, it is important that they establish practices within these projects, and within the corporations themselves, that will enable and increase investor confidence and overall performance. International investor confidence will be an important factor for South African business, and high standards of corporate governance will provide some assurance in this area [2]. The International Corporate Governance Network (an organisation established in 1995, comprising a number of large institutional investors) has established that good governance of a corporation is an essential factor, along with financial criteria, that investors take into consideration when making asset allocations and investments [6].

In associating governance with project management against the background of future investment plans in South Africa, this article aims to provide a framework within which the best governance principles and practices emerging from current trends can be incorporated into the management of projects.

\section{CORPORATE GOVERNANCE}

According to Vinten [16], corporate governance dates back to the $19^{\text {th }}$ century, when incorporation with limited liability became a reality, and there was a need for legislation and regulation. Recent debates around governance focus on the accountability of those who control companies and that of the shareowners who have a residual financial interest in a company's success. The King Committee on Corporate Governance was formed in 1992, to consider corporate governance in 
South Africa in the light of increasing interest in this subject internationally. The Committee published its first report, King Report on Corporate Governance (known as the "King Report 1994" or "King I Report”) in 1994. In March 2002 the King Committee published the King Report on Corporate Governance for South Africa 2002 (also known as the "King II Report") [7]. The need for this second study was heightened by South Africa's social and political transformation towards democracy and by her re-admission into the world economy.

According to the King II Report, the seven characteristics of good corporate governance are:

- Discipline - a commitment by senior management to adhere to behaviour that is universally accepted as correct and proper.

- Transparency - this reflects the level at which investors can obtain a true picture of what is happening in a company, and is characterized by management's ability to make information available in a candid, accurate, and timely manner.

- Independence - this refers to mechanisms that have been put in place to minimize potential conflicts of interest and the dominance of strong parties, such as the chief executive or a large shareholder.

- Accountability - mechanisms must exist and be effective to allow decisionmakers to be accountable for their decisions and actions.

- Responsibility - this refers to behaviour that allows for corrective actions and for penalizing mismanagement, and requires that the Board act responsibly towards all stakeholders.

- Fairness - systems must be balanced in taking into account all those who have an interest in the company.

- Social responsibility - response to social issues with a high priority, based on ethical standards.

Apart from general corporate governance principles, the King II Report also recommended that the following entities adopt the Code of Corporate Practices and Conduct: all companies listed on the Johannesburg Securities Exchange of South Africa; banks, insurance, and financial entities within the financial services sector of South Africa; public sector enterprises and agencies falling under the Public Finance Management Act (PFMA) and the Local Government Municipal Finance Management Bill (including any department of State or administration in the national, provincial or local sphere of government); and certain other specified functionaries and institutions.

\section{PROJECT MANAGEMENT}

Management of projects goes back as far as 4,500 years ago. The builders of structures such as the step pyramids, Stonehenge, and magnificent temples were the first known 'project managers'. These complex projects were managed with very simple tools, without any of the sophisticated project management tools available today.

A Guide to the Project Management Body of Knowledge, 2004 (hereafter referred to 
as PMBOK [13]) defines a project as a temporary endeavour to create a unique product, service, or result. Every project has a definite beginning and end. The end is reached when the project objectives are met, or when it becomes clear that the project cannot continue because the objectives cannot be met or the need no longer exists. ("Temporary" does not refer, of course, to the outcome - the product, service, or result.)

Another important characteristic of projects is the uniqueness of their deliverables. Projects may have the same or similar outcomes, but they may have different designs, locations and contractors, among other elements. According to the PMBOK [13] another characteristic of projects is progressive elaboration. This involves developing in steps and continuing by increments. The progressive elaboration of the project's specifications must be coordinated with a proper project scope definition.

PMBOK defines project management as the application of knowledge, skills, tools, and techniques to project activities to meet project requirements [13]. Project management is accomplished through the application and integration of the project management processes of initiating, planning, executing, monitoring and controlling, and closing. The process of managing a project includes: identifying the requirements; establishing clear and achievable objectives; balancing the demands for quality, scope, time, and costs; and adapting the specifications, plans, and approach to the concerns and expectations of the various stakeholders. The "triple constraint" in project management refers to the competing project requirements of scope, time, and cost.

Grundy and Brown [5] extend the project management concept to that of strategic project management. This entails "the process of managing complex projects by combining business strategy and project management techniques in order to implement the business strategy and to deliver the organisation breakthroughs" [5]. The strategic project management process consists of five stages: defining the project, creating the project strategy, detailed project planning, implementation and control, and review and learning. A key concept of strategic project management is looking at the strengths and weaknesses of previous projects in order to build the practice of continuous improvement into project management.

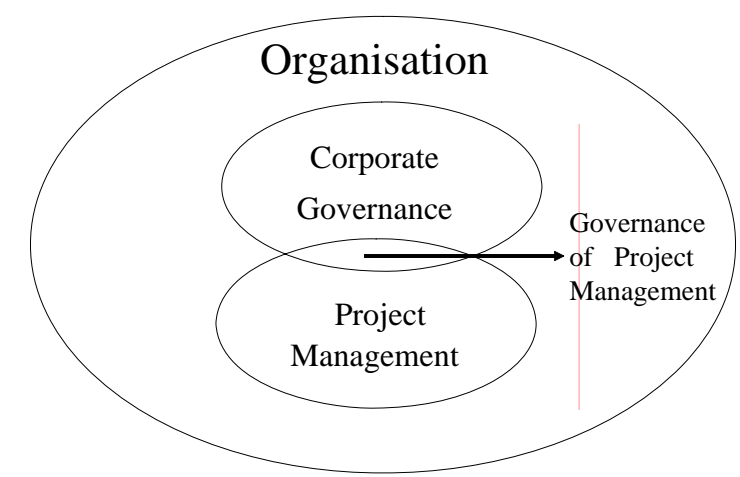

Figure 1: Scope of governance of project management (Source: Shannon 2004: 18) 


\section{PROJECT MANAGEMENT AND GOVERNANCE}

In 2004 the Association for Project Management (APM) in the United Kingdom created a specific interest group to look at the governance of project management [1]. A guide to governance was subsequently issued by the APM [15]. In issuing the guide, the interest group focused on the area of overlap between existing governance and project management. This area is illustrated in Figure 1.

According to Shannon [15], the importance of project management governance is based on whether good governance is important to the organisation, whether the discipline of project management is important to the organisation, and therefore whether organisations want the assurance that governance and project management requirements support each other. As the above figure shows, the two forces of governance and project management can be aligned to produce clear benefits to a business [15].

1 The board has overall responsibility for the governance of projects.

2 The roles, responsibilities, and performance criteria for the governance of project management are clearly defined.

3 Disciplined governance arrangements, supported by appropriate methods and controls, are applied throughout the project lifecycle.

4 A coherent and supportive relationship is demonstrated between the overall business strategy and the project portfolio.

5 All projects have an approved plan containing authorisation points at which the business case is reviewed and approved. Decisions made at authorisation points are recorded and communicated.

6 Members of delegated authorisation bodies have sufficient representation, competence, authority, and resources to make appropriate decisions.
7 The project business case is supported by relevant and realistic information that provides a reliable basis for making authorisation decisions.

8 The board or its delegated agents decide when independent scrutiny of projects and project management systems is required, and implement such scrutiny accordingly.

9 There are clearly defined criteria for reporting project status, and for the escalation of risks and issues to the levels required by the organisation.

10 The organisation fosters a culture of improvement and of frank internal disclosure of project information.

11 Project stakeholders are engaged at a level that is commensurate with their importance, and in a manner that fosters trust.

Table 1: Eleven principles for governance of projects: Source: GOPM [1] 
Seningen [14] cautions that extensive governance requirements in the corporate world can be seen to slow down project progress. However, since these requirements are a reality that cannot be ignored, being prepared for them will go a long way to alleviating some of the delays.

According to Seningen [14], governance requirements will result in a greater interest in projects, and in their increased visibility to senior executives and corporate governance members. Reporting information as accurately as possible will ensure that these requirements are met. Senior executives will be intolerant of incomplete and inaccurate project information.

Eleven principles have been identified in the GOPM (2004) for governance of project management [1]. The application of these principles will avoid common programme and project failure (Table 1).

The GOPM [1] provides key questions that should help to determine which actions to take to comply with the principles. However, the intention is not to create a complex methodology for the management of projects. The best results will come from the intelligent application of the principles, together with proportionate delegation of responsibility and monitoring of internal control systems.

\section{INVESTMENT FINANCE FOR INFRASTRACTURE PROJECTS}

According to the National Treasury Introductory Manual on Project Finance for Managers of Public Private Partnership (PPP) Projects [12], various types of funding are available. These are:

- public finance - the government borrows the funds required for an infrastructure project and gives a sovereign guarantee;

- corporate finance - a private company borrows funds and guarantees to pay lenders from operating income and its own asset base; and

- project finance - private firms may form a project company to build, own and operate an infrastructure project. The project company borrows the funds from lenders, and the lenders will look to future revenue streams from the project and to the project company's assets for future repayments.

In South Africa, given the large funding requirement, it is likely that most organisations will make use of the three funding options singly or in combination, based on long term business sustainability.

The introductory manual on Project Finance for Managers of PPP Projects lists the following as criteria that investors will set to determine the feasibility of a project [12]:

- the strength and experience of the organisations or project sponsors requesting the funding is one of the most important criteria. An important sub-criterion is the experience of the sponsor team in working together on projects; 
- qualitative and quantitative project economics. Critical financial ratios to be considered will be the liquidity ratio, leverage or gearing ratio, activity ratios, profitability ratios, net present value, internal rate of return, and other nonfinancial ratios that measure performance and efficiency;

- the credit of the project participants;

- contractual agreements between the parties stipulating responsibilities;

- financial covenants, such as minimum equity-to-debt or debt-coverage ratio;

- project risk assessments focusing on availability risk, technical and timing risk, counterparty credit risk, country or political risk, currency risk, force majeure risk, inflation risk, input and throughput risk, market (demand) risk, operating risk, regulatory risk, residual value risk, resource risk, and technology risk;

- other covenants, such as minimum asset maintenance, transfer of ownership, and restrictions on the extent of service that a sponsor may provide;

- the added value that a given sponsor may bring to the project; and

- the existing legislative environment and any incentives that the project may be able to access.

\section{DEFINING A PROJECT MANAGEMENT GOVERNANCE FRAMEWORK}

In examining the governance requirements for project management, the requirements will be considered in the context of integrating the corporate governance requirements and the project management requirements as described by Shannon [15]. The broad outline of the framework for good governance in project management is shown in Figure 2.

The framework that governs the project environment will be determined by considering the requirements for corporate governance and the project requirements. Assessment criteria based on a combination of these two requirements will be established to develop the governance structure for the organisation. In turn, the governance structure will be used to implement the corporate governance and project requirements. The process that will determine the need for, the level of intensity of, and the governance practices required within a project environment is described in the following six steps.

\section{Step 1: Organisational impact assessment}

Projects are undertaken to add value to an organisation. However, given that the project and the project management process will face certain risks, executive management must consider the impact of these risks on the value of the organisation, and decide on the appropriate level of governance to be applied to the project. Projects that require large investments of resources should be governed with more consideration than smaller projects. If the project has a minimal impact on the business value, management may decide to govern the project within existing governance structures. However, if the impact is significant, the need for and requirements of a governance structure for projects will have to be considered. This may involve developing a new governance structure, or combining new governance requirements with an existing structure. 


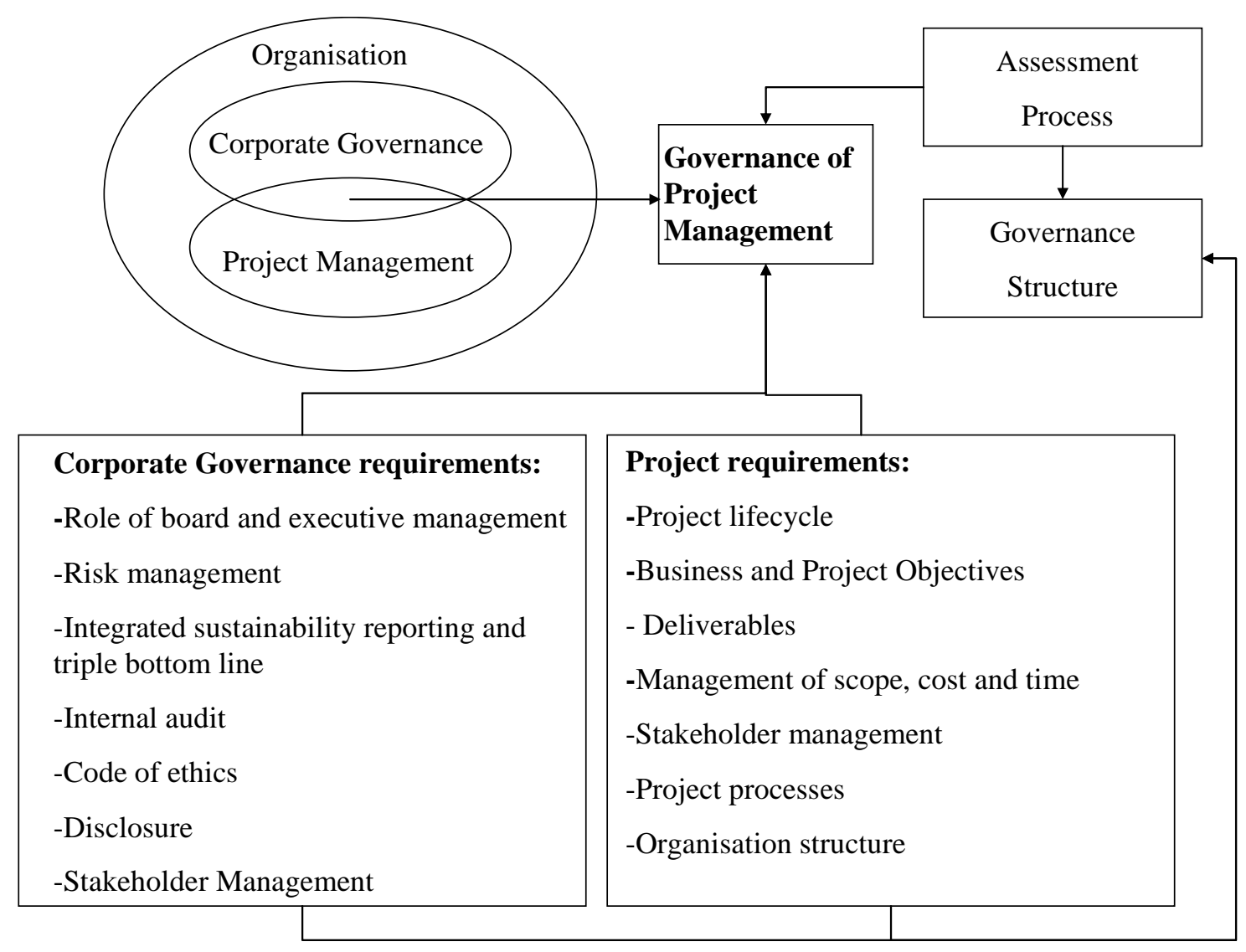

Figure 2: Broad outline of the framework for governance in project management

\section{Step 2: Assessment of governance criteria}

To determine the requirements for the governance structure, key aspects of project governance must be assessed in terms of the impact on the project and the impact on the total business. Table 2 sets out each of these requirements and suggests possible impacts for consideration. The table uses high $(\mathrm{H})$, medium $(\mathrm{M})$, and low $(\mathrm{L})$ to indicate the impact of each requirement on both the project and the business.

The table should be used to review every requirement, and to determine the impact of each on the project and on the organisation. The impacts may be different for different organisations, considering the nature of the project, its relationship to the business, and the environment within which the business operates. Once the level of impact for each requirement is determined, it should be applied to the governance matrix.

\section{Step 3: Determination of the governance matrix}

The level of impact for each of the requirements should be plotted in the matrix in Figure 3. If the impacts generally fall within the downward diagonal matrix area, 
consideration should be given to taking decisions by the board or by an executive level committee. If the impacts fall within the dotted area, consideration

\begin{tabular}{|c|c|c|c|c|}
\hline $\begin{array}{l}\text { REQUIRE- } \\
\text { MENT }\end{array}$ & \multicolumn{2}{|c|}{ IMPACT ON PROJECT } & \multicolumn{2}{|c|}{$\begin{array}{l}\text { IMPACT ON OVERALL } \\
\text { BUSINESS }\end{array}$} \\
\hline \multirow{3}{*}{$\begin{array}{l}\text { Assessment } \\
\text { of need for } \\
\text { the project }\end{array}$} & & & $\mathrm{H}$ & $\begin{array}{l}\text { Long term sustainability is } \\
\text { impacted without project }\end{array}$ \\
\hline & & & M & $\begin{array}{l}\text { Imposes constraints on } \\
\text { business performance }\end{array}$ \\
\hline & & & $\mathrm{L}$ & $\begin{array}{l}\text { Business impacts can be } \\
\text { mitigated in the short term }\end{array}$ \\
\hline \multirow{3}{*}{$\begin{array}{l}\text { Choice of } \\
\text { investment } \\
\text { options to } \\
\text { meet the } \\
\text { project need }\end{array}$} & & & $\mathrm{H}$ & $\begin{array}{l}\text { Overall financing ability } \\
\text { and credit rating impacted }\end{array}$ \\
\hline & & & M & $\begin{array}{l}\text { Constraints on financing } \\
\text { ability }\end{array}$ \\
\hline & & & $\mathrm{L}$ & $\begin{array}{l}\text { No impact on financing } \\
\text { ability or credit rating }\end{array}$ \\
\hline \multirow[t]{3}{*}{$\begin{array}{l}\text { Project / } \\
\text { business } \\
\text { objectives }\end{array}$} & $\mathrm{H}$ & $\begin{array}{l}\text { Limited ability to meet } \\
\text { objectives due to } \\
\text { unforeseen constraints }\end{array}$ & $\mathrm{H}$ & $\begin{array}{l}\text { Business performance } \\
\text { severely impacted by } \\
\text { unforeseen project } \\
\text { constraints }\end{array}$ \\
\hline & M & $\begin{array}{l}\text { Moderate limitations on } \\
\text { ability to meet objectives } \\
\text { due to unforeseen } \\
\text { constraints }\end{array}$ & M & $\begin{array}{l}\text { Moderate impact on } \\
\text { business performance } \\
\text { arising from unforeseen } \\
\text { project constraints }\end{array}$ \\
\hline & $\mathrm{L}$ & $\begin{array}{l}\text { Project objectives will be } \\
\text { met despite unforeseen } \\
\text { constraints }\end{array}$ & $\mathrm{L}$ & $\begin{array}{l}\text { Business objectives will be } \\
\text { met despite unforeseen } \\
\text { project constraints }\end{array}$ \\
\hline \multirow[t]{3}{*}{$\begin{array}{l}\text { Appointment } \\
\text { of staff }\end{array}$} & $\mathrm{H}$ & Skills shortages & $\mathrm{H}$ & $\begin{array}{l}\text { Impacts skills availability } \\
\text { across the organisation }\end{array}$ \\
\hline & M & Limited skills availability & M & $\begin{array}{l}\text { Moderate organisational } \\
\text { impact }\end{array}$ \\
\hline & $\mathrm{L}$ & Skills freely available & $\mathrm{L}$ & No organisational impact \\
\hline \multirow{3}{*}{$\begin{array}{l}\text { Stakeholder } \\
\text { identification } \\
\text { and needs } \\
\text { analysis }\end{array}$} & $\mathrm{H}$ & $\begin{array}{l}\text { Numerous, complex } \\
\text { stakeholders and } \\
\text { requirements }\end{array}$ & $\mathrm{H}$ & $\begin{array}{l}\text { Impact from stakeholder } \\
\text { relations on business } \\
\text { sustainability }\end{array}$ \\
\hline & M & $\begin{array}{l}\text { Moderate number and less } \\
\text { complex stakeholder } \\
\text { requirements }\end{array}$ & M & $\begin{array}{l}\text { Moderate impact on } \\
\text { business sustainability }\end{array}$ \\
\hline & $\mathrm{L}$ & $\begin{array}{l}\text { Stakeholder numbers and } \\
\text { requirements can be } \\
\text { easily managed }\end{array}$ & $\mathrm{L}$ & $\begin{array}{l}\text { Limited or no impact on } \\
\text { business sustainability }\end{array}$ \\
\hline $\begin{array}{l}\text { Risk } \\
\text { management }\end{array}$ & $\mathrm{H}$ & $\begin{array}{l}\text { High expected risks } \\
\text { impact to project } \\
\text { outcomes }\end{array}$ & $\mathrm{H}$ & $\begin{array}{l}\text { Project risk has a high } \\
\text { impact on business } \\
\text { performance }\end{array}$ \\
\hline
\end{tabular}




\begin{tabular}{|c|c|c|c|c|}
\hline & M & $\begin{array}{l}\text { Moderate impact of risks } \\
\text { on project outcomes }\end{array}$ & M & $\begin{array}{l}\text { Project risk has a moderate } \\
\text { impact on business } \\
\text { performance }\end{array}$ \\
\hline & $\mathrm{L}$ & $\begin{array}{l}\text { Low impact of risk on } \\
\text { project outcomes }\end{array}$ & $\mathrm{L}$ & $\begin{array}{l}\text { Low impact on business } \\
\text { performance }\end{array}$ \\
\hline \multirow[t]{3}{*}{$\begin{array}{l}\text { Internal } \\
\text { controls }\end{array}$} & $\mathrm{H}$ & $\begin{array}{l}\text { Complex control } \\
\text { environment with low } \\
\text { level of control } \\
\text { development }\end{array}$ & $\mathrm{H}$ & $\begin{array}{l}\text { Control structure could } \\
\text { affect organisational } \\
\text { controls }\end{array}$ \\
\hline & M & $\begin{array}{l}\text { Moderately complex } \\
\text { control environment }\end{array}$ & M & $\begin{array}{l}\text { Moderate impact on } \\
\text { organisational controls }\end{array}$ \\
\hline & $\mathrm{L}$ & $\begin{array}{l}\text { Well developed controls } \\
\text { and simple control } \\
\text { environment }\end{array}$ & $\mathrm{L}$ & $\begin{array}{l}\text { Very limited or no impact } \\
\text { on organisational controls }\end{array}$ \\
\hline \multirow[t]{3}{*}{ Procurement } & $\mathrm{H}$ & $\begin{array}{l}\text { High value, complex } \\
\text { supplier contracts }\end{array}$ & $\mathrm{H}$ & $\begin{array}{l}\text { High value contracts that } \\
\text { affect the broader } \\
\text { organisational supply } \\
\text { strategy }\end{array}$ \\
\hline & M & $\begin{array}{l}\text { Medium value contracts } \\
\text { with moderately complex } \\
\text { terms and conditions }\end{array}$ & M & $\begin{array}{l}\text { Moderate impact on supply } \\
\text { strategy }\end{array}$ \\
\hline & $\mathrm{L}$ & $\begin{array}{l}\text { Simple, low value } \\
\text { contracts }\end{array}$ & $\mathrm{L}$ & $\begin{array}{l}\text { Limited or no impact on } \\
\text { supply strategy }\end{array}$ \\
\hline
\end{tabular}

Table 2: Assessment criteria for governance requirements

should be given to taking decisions at an executive or project level. It must be noted that if decisions are to be taken at a project level, sufficient independence in decision-making should be assured.

Given the requirements for the impact assessment, Table 3 below suggests which committees can couple the requirements. Considerations for committees will be whether the requirement is a strategic or operational requirement. The level of the committee will be determined by coupling the impact with the area in which it falls within the governance matrix in Figure 3.

\section{Step 4: Governance structure}

Once a decision has been taken on the governance levels, based on the outcomes of the governance matrix (Figure 3), the governance structure will have to be complied with. Figure 4 contains a governance structure that corresponds to the recommendations of the King II Report, and includes the committees recommended in terms of the requirements set out in Table 4.

The same recommended committees can also be implemented at an executive management level, with sub-committees reporting to the executive committee. If the need for a project committee is determined, this committee can also report to the 
executive committee.

Although the King II Report recommends a remuneration committee, it will have no role to play with regard to the project governance requirements. It may continue to play a corporate governance role for director and executive remuneration and succession management.

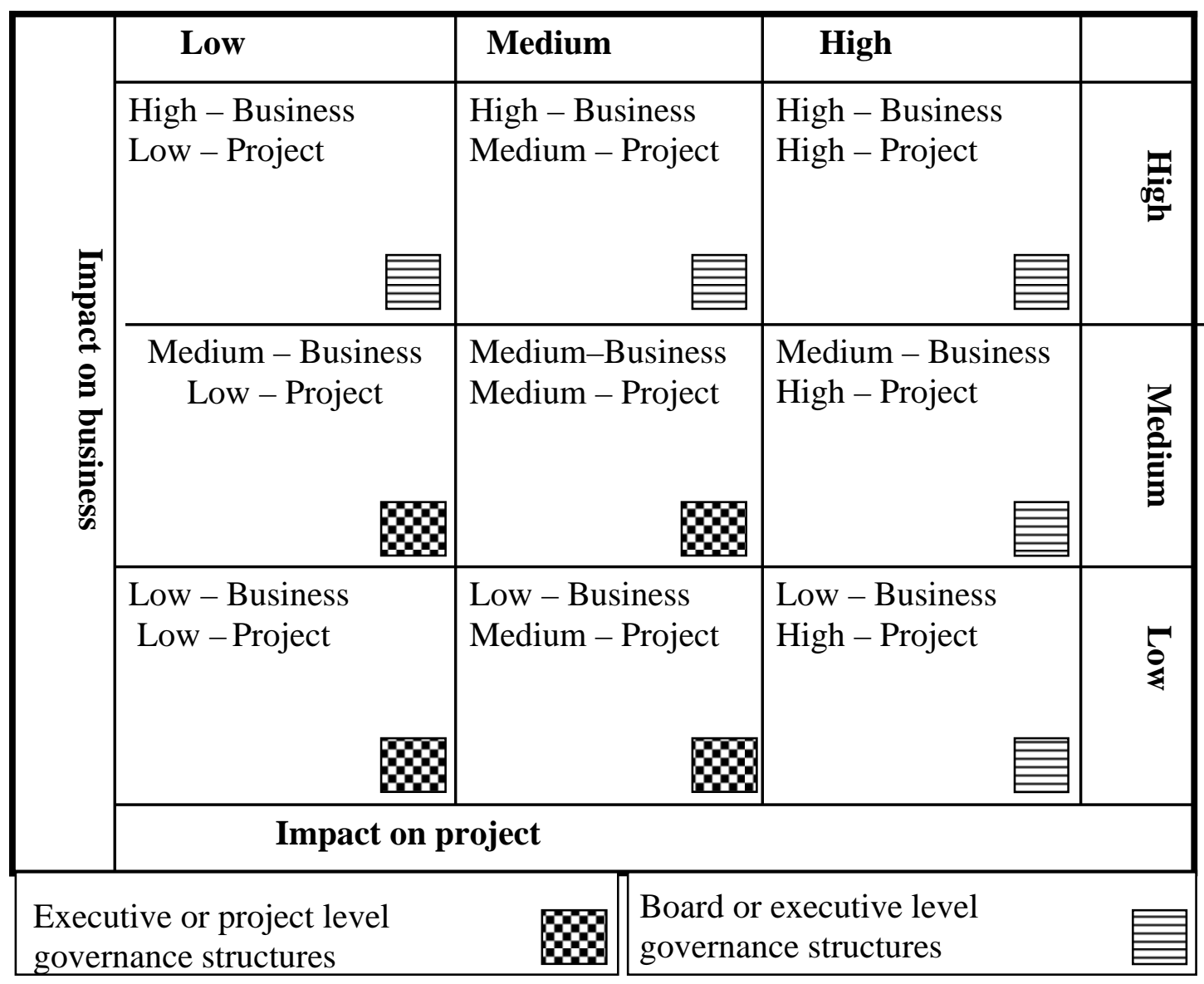

Figure 3: Governance matrix

\begin{tabular}{|l|l|}
\hline REQUIREMENT & COMMITTEE \\
\hline Need for the project & Strategic - Board or executive committee \\
\hline Choice of project options & Strategic - Board or executive committee \\
\hline Business objectives & Strategic - Board \\
\hline Project objectives & Strategic - executive committee \\
\hline Appointment of staff & Operational - executive or project committee \\
\hline Stakeholder management & Strategic - Board or executive committee \\
\hline Risk management & Operational - executive or project committee \\
\hline Internal controls & Operational - executive or project committee \\
\hline Procurement & Operational - executive or project committee \\
\hline
\end{tabular}

Table 3: Governance committees 


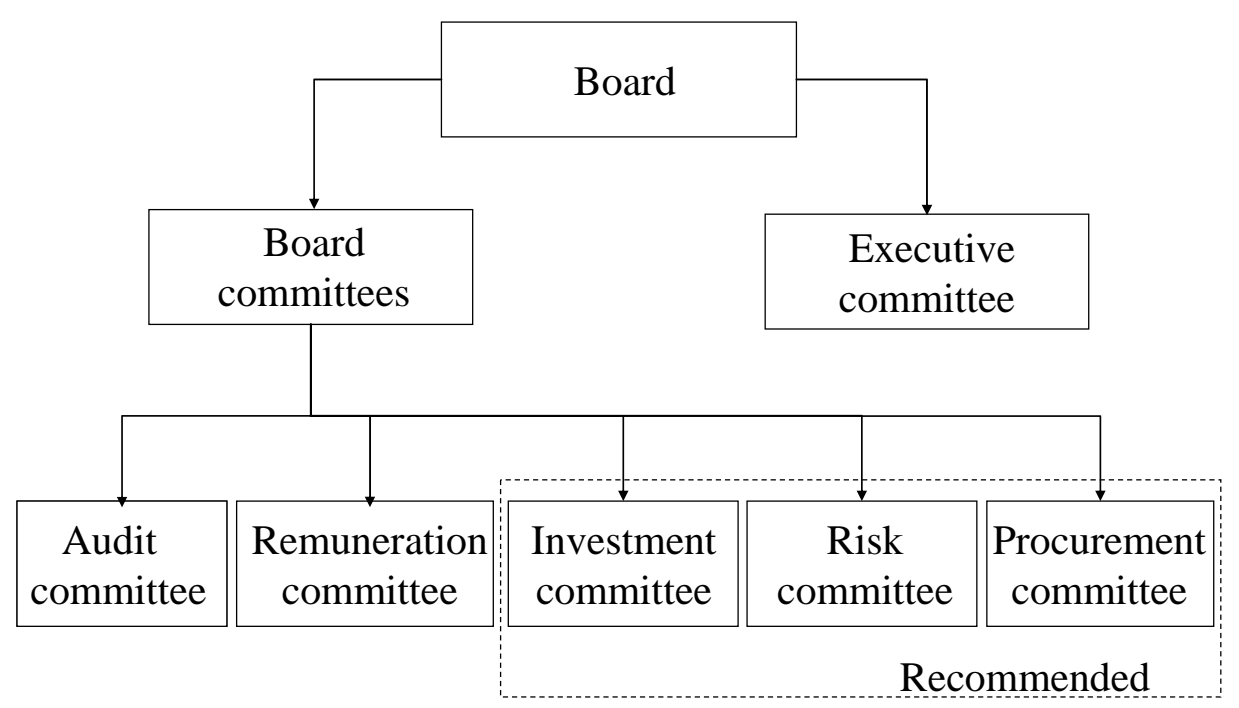

Figure 4: Governance structure

\section{Step 5: Governance practices}

Once the governance structure has been set up, management must ensure that the committees are set up for efficient operation and credible decision-making. During the project lifecycle, the various stages of the lifecycle and the knowledge areas will produce outputs that will contribute to the overall achievement of the project. Decisions about whether or not the outputs are acceptable, and whether or not they can be implemented, will have to taken within the various governance committees. One of the reasons for spreading the decision-making on outputs between the committees is to ensure that the correct level of knowledge is applied to the decisionmaking. Table 4 identifies the outputs in a typical project lifecycle, and suggests committees where these outputs may be approved.

\begin{tabular}{|l|l|}
\hline OUTPUT & APPROVAL COMMITTEE \\
\hline Project Charter & Executive Committee \\
\hline Business Case & Investment Committee \\
\hline Scope Statement & Executive / Project Committee \\
\hline Stakeholder Management Plan & Executive Committee \\
\hline Project Implementation / Execution Plan & Executive / Project Committee \\
\hline Procurement Strategy & Procurement Committee \\
\hline $\begin{array}{l}\text { Project Integrated Risk Assessment and } \\
\text { Management Plan }\end{array}$ & Risk Committee \\
\hline Financial Plan / Budget & \\
\hline Progress Reports & Executive Committee \\
\hline Finalisation and Close-out Report & Executive Committee \\
\hline
\end{tabular}

Table 4: Project output approvals

Provided that it is within the scope of its own authority and delegation, the executive committee may delegate any of the approvals indicated in the table above to a 
committee that it feels has the requisite skills and knowledge to make decisions required for the delegated approval. As part of the governance practices, reporting is a key focus area for strategic reporting, performance reporting, and sustainability reporting.

\section{Strategic reporting}

This will provide feedback to executive management and to the board on project performance against the project objectives and against overall business objectives. Included in this area of reporting should be a bi-annual risk assessment and mitigation plan. This information will reassure management that risks are being identified, assessed and managed, and will also inform management whether there are any risks facing the project that warrant discontinuing the project, or making any other strategic changes to the project objectives.

\section{Performance reporting}

Management will set specific performance criteria for the project and for the project management process. The project manager will have to report the project performance against these criteria. In some aspects in this area, such as cost and time, it may be possible to quantify targets against the performance criteria, and then measure actual quantified performance against these targets.

\section{Triple bottom line / sustainability reporting}

Many of the aspects from strategic and performance reporting may be repeated in this area. However, this area will focus on reporting on economic, social, and environmental performance. Economic reporting will comprise financial performance and performance in meeting other non-financial objectives (such as the integrity of the procurement process and strength of internal controls). Environmental performance reports must be based on contributions to improving or sustaining the physical environment of the project, or against any environmental management targets prescribed by the regulatory authorities. Social reporting should focus on targets of introducing employment equity and black economic empowerment into the project management environment. Black economic empowerment targets may extend to the procurement process, and may not be confined to the company alone. The board will set these targets in accordance with the overall corporate governance requirements. Social reporting should also extend to any community-based programmes that the project management or staff is pursuing in the local communities where the project is based. Another key aspect of sustainability reporting will be reporting compliance with the company's code of ethics. This is important in a project environment, given the interaction of project staff with contractors and other suppliers through the procurement process.

\section{Step 6: Monitoring and evaluation}

It is important to evaluate the efficiency and effectiveness of the governance within the project environment, as well as within the organisation as a whole. The 
effectiveness of some aspects of project management - such as setting goals and objectives, and the effectiveness of reporting - may be assessed out of the project environment when decision-making committees evaluate the committee performance. Management should define the frequency with which the governance structure should be reviewed, and the criteria against which the review should be conducted.

It is important that strengths and deficiencies are identified in the governance structure and processes, and that they are documented and used either to improve existing processes or to serve as lessons when designing new processes. If there is a perceived or real risk to the company business, the internal audit function may request a review or audit of the processes and governance structures within the project management environment.

\section{CONCLUSION}

The infrastructure development projects that will be seen in South Africa in the near future will increase project requirements and funding requirements. In addition to this, many other significant projects may be undertaken by South African corporations. If South Africa and its corporations are to access international financing, it is important that the overall business environment - and particularly the project environment - is well governed. However, good governance practices are not only beneficial for financing purposes: they bring the more important benefit of contributing to overall business value by ensuring that companies are well managed and controlled.

For South African companies and other legal entities, the recommendations captured in the King II Report provide a credible basis for adopting sound corporate governance practices. In the area of project management, the challenge is to ensure that good governance practices can be implemented within the project environment.

Given that the investment plans for infrastructure and other key developments in South Africa will be significant drivers of economic growth over the next few years, it is important for entities to ensure that they are well governed to access the financing that will be required to implement these investments. It is also imperative that, if these investment plans are to be executed through projects, these projects encompass the same good governance principles. This will enable management to rely on the outcomes of the project as contributing to the overall performance and principles of the corporation.

The recommended framework in this article is intended to allow companies to consider key project criteria in determining a governance structure and practices for project management that will ensure good governance in the project environment. The framework is based on typical project practices and processes, and can therefore be applied to different organisations. 


\section{REFERENCES}

[1] APM. Directing Change - A guide to governance of project management (GOPM), [http://apm.org.uk/gopm] (accessed 1 September 2005).

[2] Becker, E. 1996. Forging Effective Governance, People Dynamics, Nov/Dec, 36-41.

[3] Duncan, W. R. 1996. A Guide to the Project Management Body of Knowledge, Project Management Institute, New Town Square.

[4] Galán, J.I. and González-Benito J. 2001. Determinant factors of foreign direct investment - some empirical evidence, European Business Review, 13(5), pp 269-278.

[5] Grundy, T. and Brown, L. 2002. Strategic Project Management: Creating Organisational Breakthroughs, Thomson Learning, Cornwall.

[6] ICGN Annual Conference. 2005. ICGN Statement on Global Corporate Governance Principles, ICGN, London.

[7] King Committee on Corporate Governance. 2002. King Report on Corporate Governance for South Africa - 2002, Institute of Directors, Johannesburg.

[8] Knutson, J. 2004. Top Management Governance, PM Network, [http://www.pmi.org] (accessed 27 July 2005).

[9] Lewis, J.P. 1995. Project Planning, Scheduling and Control - A hands on guide to bringing projects in on time and on budget, Revised edition, McGraw-Hill, USA.

[10] Manuel, T.A 2005. Budget Speech 2005, South African Parliament, Cape Town, 23 February 2005.

[11] Mbeki, T. 2005. Address of the President of South Africa, Address to the second joint sitting of the Third Democratic Parliament, 11 February 2005, Cape Town.

[12] Project Finance. 2001. Introductory Manual on Project Finance for Managers of PPP Projects (2001), National Treasury PPP Manual.

[13] Project Management Institute. 2004. A Guide to the Project Management Body of Knowledge (PMBOK ${ }^{\circledR}$ Guide). Third Edition, Project Management Institute, Newtown Square.

[14] Seningen, S. 2005. Governance in the new Corporate World and how it affects Project Management, [http://www.projectperfect.com.au] (accessed 27 July 2005).

[15] Shannon, D. 2004. The governance of project management, British Journal of Administrative Management, October / November 2004, 18-19.

[16] Vinten, G. 2003. Enronitis - dispelling the disease, Managerial Auditing Journal, 18 (6), pp 448-455. 